\title{
Review of the exhibition: "Als Ich Can", 10 July - 6 January 2020, Kunstkammer, Kunsthistorisches Museum, Viena
}

DOI: $10.46284 / \mathrm{mkd} .2020 .8 .2 .7$

Oskar J. Rojewski

University of Silesia in Katowice

Since the end of 2011, the Royal Museum of Fine Arts Antwerp (KMSKA) has been closed to the public due to renovation work. During the period of the museum's closure a series of works from its collection have been loaned to a number of European museums, including the Kunsthistorisches Museum. As a result, a selection of the KMSKA's masterpieces of Early Netherlandish painting are being exhibited with key contemporaneous artworks across Europe.

The exhibition "Als Ich Can", currently on display in Vienna, is focused on Jan van Eyck's painting of the Madonna at the Fountain, which forms part of the KMSKA collection. On the painting's original frame the artist added a stylized inscription written in Greek-Byzantine letters that means "as best I can". Undoubtedly, the museum hosting this work and the curators Sabine Pénot, Elke Oberthaler and Katharina Uhlir can state the same, given that the exhibition is the outcome of an international collaboration between the KMSKA and specialists from the Royal Institute for Cultural Heritage (KIK-IRPA), as well as Flanders: State of the Art and sponsors such as UNIQA and Österreich Lotterien. Furthermore, the exhibition is just a foretaste of the range of activities devoted to the figure of Jan van Eyck that will be held in 2020 , the outcome of considerable institutional cooperation.

The exhibition is located in two rooms in the museum's Kunstkammer wing, whereby the exhibition space is not on a grand scale. However, given the reduced size of the works on display, all of which are internationally prestigious, the curators have used the space to perfection.

In the first room, an explanatory text offers an account of the life of Jan van Eyck, one that highlights the talent he displayed at the court of Philip the Good, where he served as valet $d u$ chambre. It also lists the privileges he was granted, as well as his subsequent renown amongst other authors such as Giorgio Vasari. Further information is also provided on the artist, which is illustrated with a reproduction of the sculptural representation of the allegory of painting designed by Carl Kundmann for the metopes of the Kunsthistorisches Museum: a striking nineteenth-century image of Jan van Eyck. At the entrance, visitors can consult the website of the Closer to van Eyck project (http://closertovaneyck.kikirpa.be), an initiative created by the KIK-IRPA that permits a close-up study of details of the painter's work and includes reproductions of the Ghent Altarpiece. A number of other artworks accompany the introductory and contextual explanation provided by this opening display: a copy of Rogier van der Weyden's portrait of Philip the Good, an image frequently used to illustrate histories of the Burgundian state; and the illuminated Prayer Book-Diptych of Philip the Good, which is exhibited open at the page representing Philip the Good and Charles the Bold. The latter is a singular and exceptional work from the ducal library, today conserved in the Austrian National Library.

The visitor then enters the second room, which in comparison is filled with artworks. The display of these paintings is divided into three sections that allow visitors to choose their own 
route around the room, as each section offers an almost independent historical perspective on Early Netherlandish painting.

In the centre of the room are the three most relevant pieces: van Eyck's Portrait of the Goldsmith Jan de Leuw and his Madonna at the fountain, accompanied by the embroidered Paraments of the Order of the Golden Fleece, which depicts the baptism of Christ and the transfiguration of Christ on Mount Tabor. The first of these works is exhibited horizontally, which enables the inscriptions on the frame to be studied in detail, whereby one can appreciate how this wholly lifelike image, painted with van Eyck's meticulous realism, also addresses its spectators with the words: Jan de (lion) on St. Ursula's day; saw the light of day 1401; I was now portrayed by Jan; van Eyck it seems that he began, 1436. The painter likewise "spoke" to his spectators in a similar manner on the frame of the Madonna at the fountain, with its the iconography of the Eleusa: as well as Als Ich Can, one can read IOHES DE EYCK ME FECIT + [com]PLEVIT ANO 1439. The latter work introduces a series of examples of compositions by Early Netherlandish painters that were reproduced in other media, such as the iconographic details depicted in the bas-relief embroidery of the Paraments that Julius von Schlosser attributed to Thierry du Chastel. The works displayed on the right-hand wall of this room offer a contrast to this singular piece of textile craftsmanship, and they include the Altarpiece of Saint John the Baptist and Saint John the Evangelist by Hans Memling, which has over the course of its history been linked to the activity of the van Eyck workshop.

The left-hand side of the exhibition is concerned with tracing the subsequent history of works by Early Netherlandish painters as part of early modern art collections. Amongst the works on display is Frans II Francken's painting of a selection of items from the wunderkammer of the Antwerp collector Peter Stevens (c. 1620-1625). Francken's image depicts Gerard David's Portrait of a Goldsmith displayed alongside other images and objects. Similarly, an episode from the provenance history of the Portrait of Cardinal Albergati is revealed. Van Eyck's painting is displayed alongside a drawing that entered the royal Viennese collection in 1732 which depicts the portrait within a gallery space containing four portraits flanked by two pilasters. Furthermore, the opportunity to examine both sides of the panel on which the Portrait of Cardinal Albergati is painted provides insights into the cataloguing methods employed in the collections of which this painting has formed a part. Exhibited alongside these images are two final paintings: one on a panel by the workshop of Rogier van der Weyden, which depicts the Madonna and Child with Saint Catherine painted on its reverse; the other a diptych of the Fall and Redemption of Man painted by Hugo van der Goes circa 1479. Both panels are stylistically very close to paintings by van Eyck.

The themes explored in this exhibition are thought-provoking and clearly presented, and with just a small number of works a range of aspects of current research on Early Netherlandish painting is addressed, including: the meticulous realism and detail of the paintings, the question of artists' copying of compositional models, and the history of these paintings within early modern art collections. Attentive analysis of the works displayed in the exhibition reveals a wealth of details linking together this selection of artworks, and this in turn offers valuable insights into the history of Flemish painting during the first half of the fifteenth century. One such detail that recurs throughout the exhibition is the treatment of the nude and the delicacy with which Flemish artists represented the human body, which can be noted in the reproduction of the wings of the Ghent Altarpiece in the first room (Adam and Eve), the Paraments of the Order of the Golden Fleece (the Baptism of Christ), the wings of Memling's Altarpiece of Saint John the 
Baptist and Saint John the Evangelist (Adam and Eve), the grisaille details painted on the frame of the Madonna with Child by Rogier van der Weyden, and the Fall and Redemption of Man by Hugo van der Goes. Although these five works are attributed to different workshops, a similitude may be noted in the naturalistic definition of the volume of the human body, which also signals the arrival of humanism in Flanders.

The exhibition catalogue, available for purchase at the Kunsthistorisches Museum, contains a prologue by Stefan Weppelmann and a series of studies by Sabine Pénot, Eike Oberhalter and Katja Schmitz von Ledebur. Pénot provides an introduction to the entwined history of the Duchy of Burgundy and Jan van Eyck, while also analysing the enigmatic signatures and inscriptions that the artist included in his work. She goes on to offer an in-depth reconstruction of the history of Flemish panel paintings in early modern art collections. Oberhalter's chapter is devoted to a technical study of the portraits of Cardinal Albergati and Jan de Leeuw. The final chapter, by von Ledebur, addresses the iconography and composition of the Paraments of the Order of the Golden Fleece. Regrettably, it overlooks a number of very important bibliographical sources for this set of garments does not discuss the polemic concerning their design, which was very probably inspired by the composition of the deesis in Jan van Eyck's Ghent Altarpiece.

The catalogue would have benefited from being prepared with greater attention to detail, given that translations are not provided for all the texts, Oberhalter's not being available in English. Similarly, the catalogue's bibliography, which focuses above all on studies published in German, lacks the most recent and relevant publications on van Eyck. Furthermore, none of the authors mention the issue of the existence, or not, of Hubert van Eyck, a question that should at least be mentioned in a publication of this standing.

With this exhibition the Kunsthistorisches Museum concludes its most recent phase of research on van Eyck's panels, a scholarly endeavour which has provided important results, and in particular a revised and more logical organization of the extensive range of data related to these works by Van Eyck and his contemporaries. The exhibition was planned to run from June until October 2019, but due to its seemingly unexpected success, it has been extended to January 2020, whereby a still greater number of visitors will be able to immerse themselves in the impressive range of works on display. Alongside the recently opened exhibition on Bernini and Caravaggio, the Early Netherlandish painters will be sure to astound visitors to the museum this winter. 